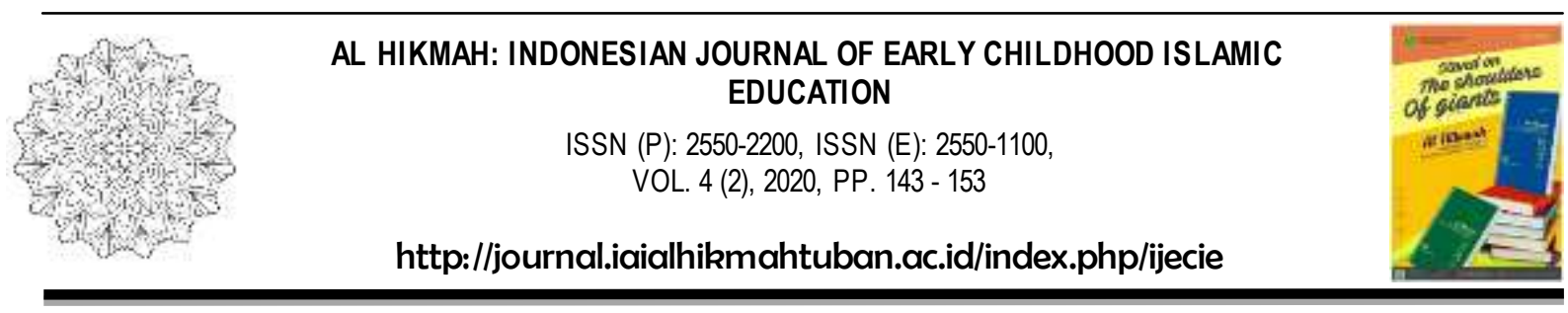

\title{
MEDIA VIDEO ANIMASI UNTUK MENGOPTIMALKAN PERKEMBANGAN KOGNITIF SISWA RA SUNAN AMPEL PASURUAN
}

\author{
Heidy Ayu Rosita ${ }^{1}$, Lukita Nurul Hidayah ${ }^{2}$, Aisyah Agus Safitri ${ }^{3}$, Hernik Farisia $^{4}$ \\ ${ }^{1234}$ Universitas Islam Negeri Sunan Ampel Surabaya \\ $\underline{\text { heidyar20@gmail.com }}$

\section{Abstrak}

Artikel ini mendeskripsikan tentang penggunaan video animasi doa sehari-hari untuk mendukung kegiatan pembelajaran selama masa pandemi serta dampaknya terhadap perkembangan kognitif siswa di RA Sunan Ampel, Pasuruan. Penelitian ini menggunakan pendekatan deskriptif kualitatif dengan instrumen. Hasil penelitian ini menunjukkan bahwa penggunaan media pembelajaran video animasi terdiri dari dua tahap, yaitu persiapan dan implementasi. Tahap persiapan adalah kegiatan awal yang dilakukan sebelum tahap penerapan video. Tahapan ini antara lain, menganalisis materi dan tujuan pembelajaran, mengidentifikasi isi video animasi, dan berdiskusi dengan teman sekelompok seputar video yang akan dipilih. Sedangkan pada tahap implementasi, dilakukan pembagian video animasi di grup Whatsapp. Sehingga anak tetap bisa belajar menggunakan media video animasi selama masa pandemi. Video ini membantu meningkatkan semangat belajar anakanak selama di rumah. Melalui kegiatan menyimak tayangan video animasi, anak-anak dapat meningkatkan kemampuan kognitifnya, yaitu menghafalkan doa dengan lancar.

Kata kunci: video animasi, media pembelajaran, perkembangan kognitif AUD.

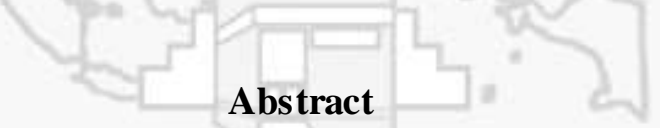

This article describes the use of animated daily prayer videos to support learning activities during the pandemic and its impact on the cognitive development of students in RA Sunan Ampel, Pasuruan. This study used a qualitative descriptive approach with instruments. The results of this study indicate that the use of video animation instructional media consists of two stages, namely preparation and implementation. The preparation stage is the initial activity carried out before the video application stage. These stages include analyzing the material and learning objectives, identifying the contents of the animated video, and discussing with a group of friends about the video to be selected. Meanwhile, at the implementation stage, the animated video was shared in the Whatsapp group. So that children can still learn to use animated video media during the pandemic. This video helps increase children's enthusiasm for learning while at home. By listening to animated video shows, children can improve their cognitive abilities, namely memorizing prayers fluently.

Keywords: video animation, instructional media, cognitive development of children. 


\section{Heidy Ayu Rosita, dkk (Media Video Animas Untuk Mengoptimalkan)}

\section{PENDAHULUAN}

Pandemi Covid-19 membuat pemerintah memberlakukan sistem Belajar dari Rumah bagi semua jenjang pendidikan yang ada di Indonesia. Termasuk juga salah satunya adalah jenjang pendidikan TK. Dalam keadaan normal tanpa adanya pandemi, anak-anak TK akan datang langsung ke sekolah dan bisa berinteraksi dengan teman-teman dan guru-gurunya. Mereka akan bermain sekaligus belajar bersama guru dan teman-temannya, di mana hal ini terasa menyenangkan bagi mereka. Anak akan bersemangat dalam belajar karena dapat merasakan perubahan suasana dan bertemu banyak orang setiap harinya. Tidak seperti keadaan sekarang yang sistem pembelajarannya di rumah saja. Hal ini terasa kurang menyenangkan bagi anak-anak TK. Selain itu juga dalam keadaan normal, dalam pengerjaan setiap tugas, anak akan diawasi langsung oleh guru. Hal ini lebih mempermudah anak mencapai perkembangan yang harus mereka capai. Di masa pandemi, sitem belajar yang digunakan adalah daring dengan cara anak-anak harus mengerjakan tugas yang disampaikan guru melalui grup Whatsapp. Kemudian tugas dikerjakan bersama Ibu, Ayah, anggota keluarga, atau kerabat lain yang ada di rumah untuk dikumpulkan mealalui grup Whatsapp juga. Sistem yang terus menerus seperti ini, dengan tidak adanya kegiatan bermain bersama teman-teman dan guru terkadang membuat anak bosan dan enggan mengerjakan tugas di rumah.

Media pembelajaran adalah instrumen yang mendukung efektifitas pembelajaran selama masa pandemi, khususnya untuk anak-anak TK yang diharuskan belajar dari rumah selama masa pandemi Covid-19 (Batubara, 2020:75). Oleh karena itu, penggunaan media pembelajaran yang interaktif dan berkualitas adalah salah satu cara untuk mendukung pembelajaran yang menyenangkan dan meningkatkan hasil belajar anak TK. Video animasi yang kami gunakan yaitu video doa sehari-hari untuk mempermudah anak-anak dalam meningkatkan kemampuan menghafal. Penelitian ini dilakukan di TK A4 RA Sunan Ampel Pasuruan. Penggunaan multimedia dalam pembelajaran merupakan suatu upaya untuk menciptakan suasana belajar yang kreatif dan inovatif tanpa mengurangi tujuan belajar yang sesungguhnya.

Pembelajaran video animasi disebut juga dengan pembelajaran yang interaktif, yang mempunyai peranan penting dalam dalam proses kegiatan pembelajaran (Batubara, 2020:75). Karena dapat memberikan pemahaman yang lebih dalam terhadap materi pembelajaran dan memberikan kesan mengurangi rasa bosan anak dalam belajar. Tujuan penelitian ini adalah 


\section{Heidy Ayu Rosita, dkk (Media Video Animas Untuk Mengoptimalkan)}

untuk menguji dampak penggunaan media pembelajaran video animasi terhadap perkembangan kognitif siswa di RA Sunan Ampel Pasuruan.

Menurut penjelasan di atas, maka dapat disimpulkan bahwa video animasi adalah kumpulan gambar yang disusun secara berurutan dan direkam menggunakan kamera untuk membuat gambar menjadi hidup dan dapat digunakan sebagai media pembelajaran.

Kemampuan kognitif diperlukan anak dalam untuk mengembangkan pengetahuan tentang apa yang dilihat, dengar, rasa, raba, ataupun cium melalui pancaindra yang dimilikinya. Pada lembaga Pendidikan Anak Usia Dini seperti di Taman Kanak-kanak, Kelompok Bermain, Pos PAUD dan lembaga pendidikan sejenis lainnya, pengembangan kognitif juga dikenal dengan istilah pengembangan daya pikir atau pengembangan intelektual (Sujiono, p. 1).

Kognisi adalah suatu proses berpikir, yaitu kemampuan individu dalam menghubungkan, menilai, dan mempertimbangkan suatu kejadian atau peristiwa. Proses kognisi berhubungan dengan tingkat kecerdasan (inteligensi) yang mencirikan seseorang dengan berbagai minat terutama ditujukan kepada ide-ide dan kegiatan belajar. Setiap individu berpikir menggunakan kemampuan inteleknya. Kemampuan inteligensi menentukan cepat tidaknya atau terselesaikan tidaknya suatu masalah yang sedang dihadapi seorang manusia. Kecerdasan merupakan kemampuan mental tertinggi yang dimiliki oleh manusia. Tingkat kecerdasan dapat membantu seseorang dalam menghadapi berbagai permasalahan yang muncul dalam kehidupannya. Kecerdasan sudah dimiliki manusia sejak lahir, dan terus menerus dapat dikembangkan hingga dewasa. Pengembangan kecerdasan akan lebih baik jika dilakukan sedini mungkin sejak anak dilahirkan melalui pemberian stimulasi pada kelima panca inderanya. William Stern menyatakan bahwa pengembangan kecerdasan anak dimulai sejak janin (sejak masih di dalam kandungan), sejak kelahirannya, dan anak memiliki lebih dari satu potensi yang secara holistik mengacu pada satu arah tertentu (Monks, Knoers dan Haditono, 1999). Pamela Minet mendefinisikan perkembangan intelektual sama dengan perkembangan mental, sedangkan perkembangan kognitif adalah perkembangan pikiran. Pikiran adalah bagian dari proses yang terjadi dalam otak. Pikiran digunakan untuk mengenali, memberi alasan rasional, mengatasi, dan memahami kesempatan penting (Sujiono, p. 1).

Berdasarkan Keputusan Direktur Jenderal Pendidikan Islam Nomor 2791 Tahun 2020 Tentang Panduan Kurikulum Darurat Pada Madrasah, pembelajaran daring yang dilakukan selama masa pandemi, penilaiannya dirancang untuk mendorong aktivitas belajar yang 
bermakna, dan tidak perlu dipaksakan mengukur ketuntasan capaian kurikulum secara menyeluruh (Direktur Jenderal, 2020:16). Dan kegiatan pembelajaran di masa darurat pandemi bukan untuk mencapai ketuntasan kompetensi dasar (KD) kurikulum semata, namum lebih menititikberatkan pada penguatan karakter, praktek ibadah, peduli pada lingkungan dan kesalehan sosial lainnya (Direktur Jenderal, 2020:8). Penguatan karakter tersebut salah satu contohnya adalah kemampuan membaca doa sehari-hari.

Indaryati dan Jailani mengatakan bahwa media pembelajaran adalah salah satu faktor utama yang dapat mempengaruhi hasil belajar siswa, karena melalui medialah pesan pembelajaran dapat disampaikan sesuai dengan tujuan pembelajaran tersebut (Febriani, 2017:13).

Korelasi antara penggunaan media video dengan pengoptimalan perkembangan kognitif dijelaskan oleh beberapa ahli. Dijelaskan bahwa penggunaan media video dapat meningkatkan kemampuan anak dalam belajar. Dan kegiatan belajar melibatkan kemampuan berfikir atau kemampuan kognitif. Kustandi dan Sutjipto berpendapat bahwa media pembelajaran merupakan alat yang dapat membantu proses belajar mengajar dan berfungsi untuk memperjelas makna pesan yang disampaikan, sehingga dapat mencapai tujuan pembelajaran dengan lebih baik dan sempurna (Febriani, 2017:13).

Manning dan Johnson menjelaskan bahwa video dapat digunakan untuk medorong kemajuan pendidikan melalui gabungan dari efek visual, dialog, demonstrasi dan yang paling baru adanya interaksi penampilan. Sehingga dengan adanya video dalam pembelajaran dapat membuat peserta didik dengan mudah memahami tujuan pembelajaran yang ingin dicapai. Maka wajar jika peserta didik yang diajar dengan bantuan media video memiliki semangat dan gairah pada saat proses pembelajaran (Febriani, 2017:14).

Melalui media video, materi pembelajaran yang akan disampaikan mampu membangkitkan semangat peserta didik untuk belajar karena materi yang dipelajari dapat dengan mudah dimengerti dan dipahami peserta didik melalui gambar, suara dan animasi yang disajikan, sehingga dapat meningkatkan motivasi belajar dan hasil belajar peserta didik. (Hal. 14) (Pengaruh Media Video terhadap Motivasi Belajar dan Hasil Belajar Kognitif Pembelajaran IPA Kelas V Sekolah Dasar) 


\section{Heidy Ayu Rosita, dkk (Media Video Animas Untuk Mengoptimalkan)}

\section{METODE}

Metode penelitian yang digunakan dalam penelitian ini adalah deskriptif kualitatif. Subjek penelitian ini adalah anak TK A4 RA Sunan Ampel Pasuruan yang mana saat ini pembelajaranya menggunakan pembelajaran daring. Jumlahnya adalah 16 siswa. Instrumen penelitian ini adalah observasi dan wawancara mendalam secara online kepada guru TK A4, terkait penggunaan media pembelajaran video animasi dalam mengoptimalkan perkembangan kognitif siswa di RA Sunan Ampel Pasuruan.

Instrumen respon guru terhadap video animasi dikembangkan berdasarkan teori Rogers (Batubara, 2020:77). Menurut Everet Rogers, penerimaan pengguna terhadap suatu inovasi dipengaruhi oleh lima faktor, yaitu yang pertama adalah keuntungan relatif (relative advantage), yaitu manfaat video animasi bagi proses pembelajaran. Tingkat keuntungan relatif tersebut dapat diukur dari aspek ekonomi, penghargaan, kenyamanan, kepuasan, dan target yang dicapai. Kedua, ada kesesuaian (compatibility), yaitu penggunaan video animasi diimplementasikan sesuai dengan kebutuhan dan keinginan siswa dan tingkat kesesuaian dalam pengimplementasian lebih baik dibanding dengan media pembelajaran yang ada sebelumnya. Yang ketiga adalah kerumitan (complexity), yaitu penggunaan video animasi dipandang sulit untuk dipahami oleh siswa. Semakin mudah siswa memahami konten video animasi maka semakin baik respons siswa terhadap penggunaan video animasi. Yang keempat ketercobaan (triability), yaitu video animasi dapat dicoba dalam kelompok kecil sebelum diujicobakan dalam kelompok besar. Sehingga mendapatkan peluang lebih cepat untuk diterima daripada inovasi yang tidak bisa diuji coba. Kelima ada keteramatan (observability), yaitu guru dapat mengamati pengaruh dari video animasi bagi proses pembelajarannya. Semakin mudah guru memahami pengaruh tersebut maka semakin besar peluang terhadap penerimaan video animasi (Rogers, 2003: 219-266).

\section{HASIL DAN PEMBAHASAN}

\section{Penggunaan Media Pembelajaran Video Animasi di Masa Pandemi Covid-19}

Selama pelaksanaan Belajar Dari Rumah (BDR), guru banyak memanfaatkan media pembelajaran berbasis digital untuk memfasilitasi proses pembelajaran dan meningkatkan capaian perkembangan anak usia dini. Dalam pengembangan aspek kognitif, guru RA Sunan Ampel menggunakan video animasi doa sehari-hari untuk mempermudah anak-anak dalam meningkatkan kemampuan menghafal. Media video animasi digunakan dengan tujuan agar 
anak-anak TK menjadi lebih tertarik dalam kegiatan pembelajaran dan tidak mudah bosan. Pembelajaran daring sangat sulit bagi anak TK. Oleh karena itu, memilih media pembelajaran video animasi sangatlah membantu dalam proses kegiatan pembelajaran. Dengan adanya video animasi, anak lebih tertarik dan semangat dalam belajar.

Penerapan video dilaksanakan melalui dua tahapan, yaitu sebagai berikut. Yang pertama ada tahap persiapan. Tahap persiapan adalah kegiatan-kegiatan awal sebelum melakukan penerapan video. Tahapan ini sangat penting karena untuk mempersiapkan video yang sesuai dengan harapan (Labasariyani \& Marlinda, 2014:95). Beberapa kegiatan yang penulis lakukan pada tahap persiapan adalah yang pertama menganalisis materi dan tujuan pembelajaran di TK, yang sudah ditetapkan di dalam Program Semester. Kedua adalah mengidentifikasi ketepatan isi video animasi dan kesesuaiannya dengan tujuan pembelajaran. Hal-hal yang menjadi pertimbangan dalam memilih video yang akan diberikan ke anak adalah antara lain, gambar animasinya menarik atau tidak, antara tulisan Arab doanya dengan suaranya apakah sudah sesuai bacaannya, dan juga pelafalannya jelas atau tidak. Terakhir adalah merancang penugasan untuk peserta didik. Tahapan kedua adalah tahap implementasi. Pada tahap implementasi, guru menerapkan model pembelajaran daring (dalam jaringan) dan luring (luar jaringan). Dalam kegiatan pembelajaran daring, guru melakukan kegiatan pemberian tugas selama seminggu melalui grup whatsapp. Setelah wali murid mengumpulkan tugas di grup, guru memberikan penilaian berupa bintang dan kata-kata pujian dan penyemangat. Respon siswa dan orang tua adalah menyambut dengan baik dengan mengiyakan tugas beserta contoh video yang diberikan. Tidak ada protes ataupun kritikan dari orang tua siswa. Video berisi gambar ayat bacaan doa yang harus dihafalkan dengan disertai gambar animasi pemandangan. Audio yang ada di dalam video adalah suara seseorang yang sedang membaca doa dengan pelafalan yang jelas dan dengan intonasi yang perlahan-lahan dan dïringi alunan lagu yang tenang (tidak mengganggu suara pelafalan doanya). Jadi anak bisa mendengarkan suara bacaan doa sambil melihat tulisan arab doa yang sedang dipelajari. Selain bahasa Arabnya, di dalam video tersebut juga disertakan tulisan serta audio terjemahannya. Siswa dapat mengulang-ulang video untuk membantunya menghafalkan doa.

Berdasarkan Keputusan Direktur Jenderal Pendidikan Islam Nomor 2791 Tahun 2020 Tentang Panduan Kurikulum Darurat Pada Madrasah, kegiatan pembelajaran di masa darurat pandemi bukan untuk mencapai ketuntasan kompetensi dasar (KD) kurikulum saja, namum lebih berfokus kepada penguatan karakter, praktek ibadah, peduli pada lingkungan dan 
kesalehan sosial lainnya (Direktur Jenderal, 2020:8). Penguatan karakter tersebut salah satu contohnya adalah kemampuan membaca doa sehari-hari.

Dalam artikel ini peneliti telah menggunakan media pembelajaran video animasi doa sehari-hari. Dengan media ini, aspek perkembangan yang dikembangkan dalam diri anak yang pertama adalah aspek perkembangan kognitif. Yaitu anak dilatih untuk menghafalkan doa sehari-hari, di mana kemampuan menghafal ini melibatkan kemampuan otak anak untuk mengolah informasi atau berpikir.

Video animasi diterapkan kepada anak-anak dalam pembelajaran daring agar dapat mempermudah mereka dalam menghafalkan. Sehingga anak dapat menerapkan doa di dalam aktivitas sehari-hari.

Perkembangan kognitif sendiri artinya adalah kemampuan individu untuk mengolah informasi, atau dalam bahasa sehari-hari biasa kita sebut dengan perkembangan berpikir. Perkembangan kognitif merupakan salah satu aspek yang harus distimulasi sejak dini. Kemampuan ini dapat dikembangkan dengan kegiatan bermain atau kegiatan yang seru, menarik, dan menyenangkan. Salah satu contoh kegiatan tersebut adalah belajar menggunakan media tertentu seperti misalnya video animasi doa sehari-hari. Melalui kegiatan mengamati dan menyimak video, siswa lebih mudah melafalkan doa sehari-hari dan mempraktikkannya di rumah. Selain itu, pengembangan pembelajaran dengan media video juga meningkatkan kemampuan siswa dalam menggunakan bahasa.

Perkembangan bahasa adalah kemampuan individu dalam mengungkapkan kata-kata atau kalimat yang berfungsi untuk alat komunikasi dengan individu lainnya. Perkembangan bahasa memiliki bagian-bagian atau aspek yang harus diperhatikan, yaitu mendengar, berbicara, menulis, dan membaca. Kemampuan mendengar anak akan mempengaruhi kemampuan berbicaranya. Hasil pendengaran anak akan diaplikasikan melalui bibirnya. Hal ini berkaitan dengan anak yang dapat menirukan apa yang didengarkannya dari video animasi doa sehari-hari. Karena di dalam video animasi tersebut terdapat audio (media suara) yang dapat didengarkan yang disertai dengan animasi yang menarik untuk untuk ditonton dan didengarkan. Anak akan lebih mudah melafalkan doa sehari-hari setelah mendengarkan video tersebut.

Bahasa anak yang pertama kali berkembang atau distimulasi adalah bahasa ibu, yaitu bahasa pertama atau bahasa asli atau bahasa utama seseorang, yang dikenal dan diucapkannya untuk berkomunikasi dengan orang-orang terdekat dan lingkungan sekitarnya. Namun tidak 
berarti second language (bahasa lain selain bahasa ibu) tidak distimulasi. Second language juga merupakan bagian terpenting dalam perkembangan bahasa anak yang sangat bermanfaat dalam komunikasi anak dalam lingkungan yang lebih luas.

Melalui video animasi doa sehari-hari, anak juga diperkenalkan dengan second language, yaitu bahasa Arab. Meskipun belum benar-benar mengerti artinya, tetapi anak sudah diajarkan untuk dapat melafalkan atau mengucapkan ayat doa dalam bahasa Arab dengan menggunakan bibirnya. Hal ini bertujuan untuk melatih dan membiasakan pengucapan bahasa Arab mereka. Harapannya adalah anak tidak akan kesusahan lagi nantinya untuk mengucapkan atau membaca doa, bacaan ayat Al-Qur'an, maupun hadis, yang mana hal ini akan terus menjadi bagian dari hidupnya, dan dipelajarinya hingga akhir hayat kelak. Karena ada beberapa kasus di mana anak sudah menginjak jenjang usia pendidikan SMP, SMA, ataupun pada jenjang usia lebih tua lagi dari itu, namun masih belum lancar melafalkan bacaan AlQur'an, belum mengerti dan mengenal bagaimana cara mengucapkan bacaan bahasa Arab yang baik dan benar, dikarenakan kurangnya pembiasaan bibir mereka dalam pengucapan bahasa Arab sejak dini. Ketidakmampuan mereka dalam melafalkan kalimat dalam bahasa Arab ini juga akan berpengaruh kepada kemampuan menghafalnya, di mana kita sebagai umat muslim akan selalu dituntut untuk bisa menghafalkan doa -doa dan ayat-ayat Al-Qur'an, baik dalam kehidupan di rumah maupun di lingkungan pendidikan (di sekolah atau di tempat mengaji).

Selain belajar melafalkan, melalui video animasi doa sehari-hari, anak juga diperkenalkan kepada arti bahasa arab dari doa tersebut. Karena di dalam video terdapat bacaan doa yang disertai dengan artinya.

Kata moral dan agama terdengar "berat" jika dibahas pada anak usia dini. Justru karena kedua hal tersebut "berat" sehingga harus diperkenalkan, dibiasakan, dan dikembangkan sejak usia dini. Moral dan agama jangan dijadikan sebagai momok yang menakutkan bagi anak. Tetapi sedikit demi sedikit diperkenalkan dan dibiasakan sehingga anak akan terbiasa dan merasa mudah, merasa bahwa hal ini juga menjadi bagian dari identitas dirinya.

Video animasi doa sehari-hari ini diterapkan dengan tujuan untuk melatih anak untuk membiasakan diri agar pikiran dan hatinya selalu dekat kepada Allah dalam setiap aktivitasnya. Yaitu dengan cara selalu membaca doa-doa saat akan melakukan sesuatu maupun selesai melakukan sesuatu. 


\section{Hasil Observasi Video Anak Menghafalkan Doa Sehari-Hari}

Dilakukann pengamatan terhadap video anak TK A4 RA Sunan Ampel Pasuruan menghafalkan doa sehari-hari, lalu hasil pengamatan kami tuangkan ke dalam tabel berikut ini beserta nilai akhirnya. Yang diamati adalah video hafalan doa masuk kamar mandi, doa memakai pakaian, dan doa melepas pakaian.

Dilakukan pengamatan terhadap video anak TK A4 RA Sunan Ampel Pasuruan menghafalkan doa sehari-hari, lalu hasil pengamatan kami tuangkan ke dalam tabel berikut ini beserta nilai akhirnya. Yang diamati adalah video hafalan doa masuk kamar mandi, doa memakai pakaian, dan doa melepas pakaian.

Tabel 1. Contoh Keterampilan Motorik pada Anak Usia Dini sesuai dengan Usianya

\begin{tabular}{|c|c|c|c|c|c|}
\hline $\begin{array}{l}\text { Materi } \\
\text { Hafalan }\end{array}$ & 1 & $\begin{array}{l}\text { Tidak } \\
\text { Lancar }\end{array}$ & $\begin{array}{l}\text { Cukup } \\
\text { Lancar }\end{array}$ & $\begin{array}{l}\text { Sangat } \\
\text { Lancar }\end{array}$ & $\begin{array}{l}\text { Tidak } \\
\text { Mengumpul }\end{array}$ \\
\hline $\begin{array}{l}\text { Doa } \\
\text { kamar } \mathrm{m}\end{array}$ & $\begin{array}{l}\text { masuk } \\
\text { nandi }\end{array}$ & $25 \%$ & $25 \%$ & $43,75 \%$ & $6,25 \%$ \\
\hline $\begin{array}{l}\text { Doa } \\
\text { pakaian }\end{array}$ & memakai & $25 \%$ & $12,5 \%$ & $25 \%$ & $18,75 \%$ \\
\hline $\begin{array}{l}\text { Doa } \\
\text { pakaian }\end{array}$ & melepas & $12,5 \%$ & $18,75 \%$ & $43,75 \%$ & $25 \%$ \\
\hline
\end{tabular}

\section{Data Pendukung Temuan Observasi}

Selain pengamatan video para siswa menghafalkan doa sehari-hari, disertakan juga data pendukung temuan observasi berupa wawancara kepada wali kelas TK A4 RA Sunan Ampel Pasuruan, yaitu Ibu Aisyah Agus Safitri S. Pd. Media pembelajaran yang digunakan adalah video animasi doa sehari-hari. Video didapatkan dengan cara didownload dari youtube. Sedangkan subjek yang diteliti adalah para siswa di TK A4 RA Sunan Ampel Pasuruan. Berikut ini adalah pertanyaan sekaligus jawaban yang ada di dalam wawancara tersebut.

Pertanyaan pertama adalah tentang hasil yang didapatkan terkait kemampuan siswa dalam menghafal setelah pemberian media video animasi, lebih baik atau tidak jika di bandingkan dengan sebelum menggunakan media. Jawaban dari wali kelas yaitu hasil yang didapatkan lebih baik jika dibandingkan dengan sebelum diberi media video animasi. Menurut wali kelas, dengan adanya video animasi seperti yang dicontohkan saat pembelajaran daring 
berlangsung, anak-anak jadi lebih semangat dalam menghafal surat pendek ataupun doa sehari-hari. Karena videonya lebih menarik untuk anak.

Pertanyaan kedua yaitu mengenai berhasil atau tidaknya anak-anak mencapai target yang diinginkan dengan bantuan media video animasi. Hal ini dapat dilihat dari kemampuan anak dalam menirukan dan menghafalkan. Jawabannya adalah anak-anak dapat mencapai tujuan perkembangan yang diinginkan. Karena dengan adanya media video serta dengan bantuan orang tua di rumah, anak dapat menghafalkan menggunakan media video tersebut.

Pertanyaan ketiga adalah tentang pengaruh pemberian contoh doa sehari-hari dalam bentuk video ini terhadap pembelajaran di TK A4. Jawabannya yaitu video animasi sangat berpengaruh terhadap pembelajaran. Intinya dengan adanya media video animasi, dapat mempermudah dan mendukung kemampuan anak dalam menghafalkan doa sehari-hari dan surat-surat pendek. Anak menjadi lebih semangat dan berlomba-lomba menghasilkan yang terbaik (dalam hal ini menyetorkan tugas hafalan di grup Whatsapp).

Pertanyaan keempat yaitu tentang cara guru menangani orang tua agar tetap semangat mendampingi anaknya dalam kegiatan pembelajaran. Karena meskipun sudah diberi media video animasi, jika orang tua kurang bersemangat dalam membimbing anak, anak akan menjadi kurang bisa dalam menghafalkan doa sehari-hari. Selain itu juga agar anak tetap bisa mengikuti pelajaran tepat waktu sesuai dengan jadwal, dan tidak terlambat menyetorkan video hafalan. Jawaban untuk pertanyaan ini adalah guru menangani hal ini dengan cara terus menerus memotivasi anak dan orang tua dengan memberikan pujian, ucapan terima kasih, dan sebagainya (saat anak mengumpulkan tugasnya di grup Whatsapp. Bahkan bila perlu, guru menghubungi orang tua siswa yang kurang semangat tersebut secara pribadi dan menanyakan alasan keterlambatan pengumpulan tugas anak. Kemudian guru memberikan semangat dan arahan agar tidak terlambat lagi dalam pengumpulan tugas. Hal ini adalah sebagai wujud pemberian perhatian guru kepada orang tua siswa sebagai wali kelas.

\section{PENUTUP}

\section{Simpulan}

Video animasi yang dibahas dalam jurnal ilmiah ini diberikan kepada anak-anak TK sebagai media pembelajaran pada masa pandemi. Video animasi yang kami gunakan yaitu video doa sehari-hari untuk mempermudah anak-anak dalam meningkatkan kemampuan menghafal. Aspek-aspek perkembangan yang dapat dicapai melalui media pembelajaran video 
animasi antara lain aspek kognitif, bahasa, moral, dan agama. Subjek penelitian adalah para siswa di TK A4 RA Sunan Ampel Pasuruan. Kami mengamati video yang berisikan anak menghafalkan doa sehari-hari, lalu hasil pengamatan kami tuangkan ke dalam sebuah tabel berisi presentase jumlah siswa yang dalam menghafalkan itu tidak lancar, cukup lancar, sangat lancar, dan yang tidak mengumpulkan video hafalan. Kami mengamati video hafalan doa masuk kamar mandi, doa memakai pakaian, dan doa melepas pakaian. Dalam wawancara yang diajukan kepada wali kelas TK A4, semua jawaban mengarah ke jawaban positif, yang artinya menunjukkan bahwa video animasi doa sehari-hari ini membawa hasil yang baik untuk digunakan di masa pandemi sebagai sarana belajar anak untuk memberikan semangat mereka menghafalkan doa-doa. Hal ini juga berbanding lurus dengan hasil pengamatan hafalan doa masuk kamar mandi dan doa melepas pakaian di mana sebesar 43,75\% siswa dapat menghafalkannya dengan sangat lancar.

\section{Saran}

Selain pemberian media video animasi, peran orang tua juga sangat penting untuk mendukung anak menghafalkan doa sehari-hari. Karena menghafalkan juga membutuhkan waktu yang tidak singkat, sehingga harus dilatih setiap hari. Sedangkan biasanya, dari pihak sekolah memberikan video contoh doa sehari-hari kurang dari seminggu, lalu harus sudah disetorkan hafalannya beberapa hari kemudian. Jadi kalau ada doa yang belum pernah dikenal anak sebelumnya, akan membuat anak kesusahan menghafalkan doa yang diminta. Mungkin dari pihak sekolah juga bisa memberitahukan kepada siswa di awal semester untuk mempersiapkan hafalan doa yang harus disetorkan. Agar anak dan orang tua dapat bersiap-siap menghafalkannya.

\section{DAFTAR PUSTAKA}

Batubara, Hamdan Husein. (2020). Penggunaan Video Tutorial Untuk Mendukung Pembelajaran Daring Di Masa Pandemi Virus Corona. Banjarmasin, Indonesia: Muallimuna Jurnal Madrasah Ibtidaiyah

Febriani, Corry. (2017). Pengaruh Media Video Terhadap Motivasi Belajar dan Hasil Belajar Kognitif Pembelajaran IPA Kelas V Sekolah Dasar. Palangka Raya, Indonesia: Jurnal Prima Edukasia

Sujiono, Yuliani Nurani. MODUL 1 Hakikat Pengembangan Kognitif.

Direktur Jenderal Pendidikan Islam. (2020). Keputusan Direktur Jenderal Pendidikan Islam Nomor 2791 Tahun 2020 Tentang Panduan Kurikulum Darurat Pada Madrasah. 